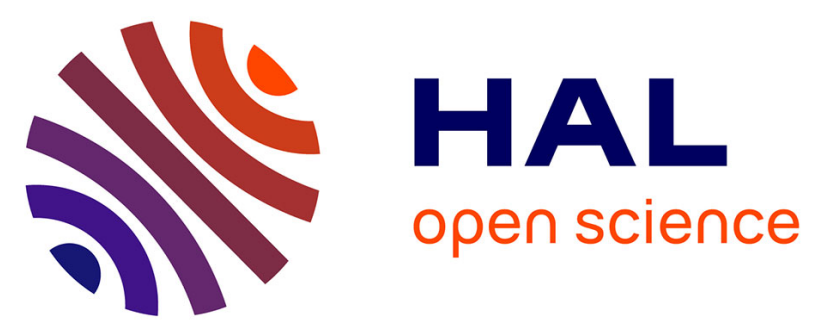

\title{
Agronomy for sustainable agriculture. A review
}

Eric Lichtfouse, Mireille Navarrete, Philippe Debaeke, Véronique Souchère, Caroline Alberola, Josiane Ménassieu

\section{To cite this version:}

Eric Lichtfouse, Mireille Navarrete, Philippe Debaeke, Véronique Souchère, Caroline Alberola, et al.. Agronomy for sustainable agriculture. A review. Agronomy for Sustainable Development, 2009, 29 (1), pp.1-6. 10.1051/agro:2008054 . hal-00350465v2

\section{HAL Id: hal-00350465 https://hal.science/hal-00350465v2}

Submitted on 6 Feb 2010

HAL is a multi-disciplinary open access archive for the deposit and dissemination of scientific research documents, whether they are published or not. The documents may come from teaching and research institutions in France or abroad, or from public or private research centers.
L'archive ouverte pluridisciplinaire HAL, est destinée au dépôt et à la diffusion de documents scientifiques de niveau recherche, publiés ou non, émanant des établissements d'enseignement et de recherche français ou étrangers, des laboratoires publics ou privés.

$$
\text { Copyright }
$$




\title{
Review article
}

\section{Agronomy for sustainable agriculture. A review}

\author{
Eric LichtFouse ${ }^{1 *}$, Mireille NAVARrete ${ }^{2}$, Philippe DebaeKE $^{3}$, Véronique SouchèrE $^{4}$, Caroline Alberola ${ }^{5}$, \\ Josiane MÉNASSIEU ${ }^{6}$ \\ ${ }^{1}$ INRA, Editor-in-Chief, Journal Agronomy for Sustainable Development, INRA-CMSE-PME, 17 rue Sully, 21000 Dijon, France \\ ${ }^{2}$ INRA, Associate Editor, Unité SAD Ecodéveloppement, 84914 Avignon Cedex 09, France \\ ${ }^{3}$ INRA, Associate Editor, UMR AGIR, BP 52627, 31326 Toulouse Cedex, France \\ ${ }^{4}$ INRA, UMR SAD APT, INRA-INA PG, BP 01, 78850 Thiverval Grignon, France \\ ${ }^{5}$ INRA, Editorial Assistant, journal Agronomy for Sustainable Development, Bât. PSH-B, Site Agroparc, 84914 Avignon Cedex 9, France \\ ${ }^{6}$ Past-Editorial Secretary, Hameau de Besses, Ancienne École, 07310 Saint-Martial, France
}

(Accepted 1 October 2008)

\begin{abstract}
Sustainability rests on the principle that we must meet the needs of the present without compromising the ability of future generations to meet their own needs. Starving people in poor nations, obesity in rich nations, increasing food prices, on-going climate changes, increasing fuel and transportation costs, flaws of the global market, worldwide pesticide pollution, pest adaptation and resistance, loss of soil fertility and organic carbon, soil erosion, decreasing biodiversity, desertification, and so on. Despite unprecedented advances in sciences allowing us to visit planets and disclose subatomic particles, serious terrestrial issues about food show clearly that conventional agriculture is no longer suited to feeding humans and preserving ecosystems. Sustainable agriculture is an alternative for solving fundamental and applied issues related to food production in an ecological way (Lal (2008) Agron. Sustain. Dev. 28, 57-64.). While conventional agriculture is driven almost solely by productivity and profit, sustainable agriculture integrates biological, chemical, physical, ecological, economic and social sciences in a comprehensive way to develop new farming practices that are safe and do not degrade our environment. To address current agronomical issues and to promote worldwide discussions and cooperation we implemented sharp changes at the journal Agronomy for Sustainable Development from 2003 to 2006. Here we report (1) the results of the renovation of the journal and (2) a short overview of current concepts of agronomical research for sustainable agriculture. Considered for a long time as a soft, side science, agronomy is rising fast as a central science because current issues are about food, and humans eat food. This report is the introductory article of the book Sustainable Agriculture, volume 1, published by EDP Sciences and Springer (Lichtfouse et al. (2009) Sustainable Agriculture, Vol. 1, Springer, EDP Sciences, in press).
\end{abstract}

sustainable agriculture / climate change / biodiversity / agronomy for sustainable development / organic farming / pest control / food / water / soil / pesticide / farming system

\section{Foreword}

This article is dedicated to Ms. Josiane Ménassieu. Josiane was the Editorial Secretary of the journal Agronomy for Sustainable Development (ASD) from 2003 and retired in April 2008. The success of the renovation of the journal from 2003 to 2006 is mainly due to her intensive work. Her kindness was greatly appreciated by authors, peer-reviewers and Field Editors. Figure 1 shows a picture of the present that was offered to her by colleagues for her retirement.

\section{THE JOURNAL AGRONOMY FOR SUSTAINABLE DEVELOPMENT}

Agronomy for Sustainable Development (ASD, agronomyjournal.org) is one of the seven journals of the French Institute

* Corresponding author: Eric.Lichtfouse@ dijon.inra.fr

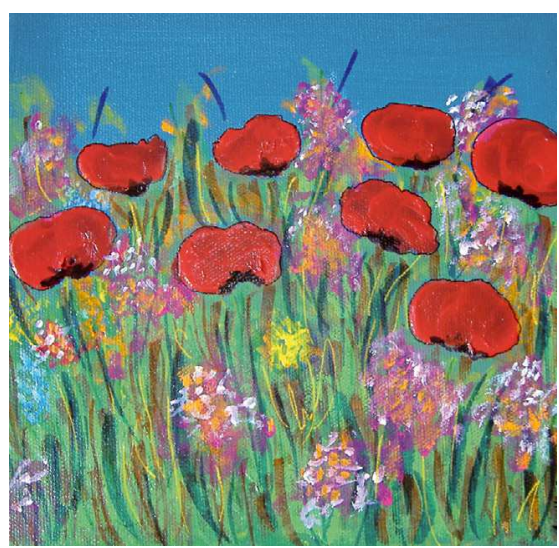

Figure 1. Coquelicots painting by artist Agathe Rémy, who lives near Aix-en-Provence, France. Coquelicots is the French word for poppies. 
Impact factor

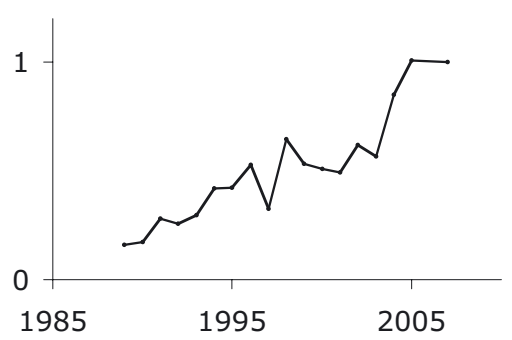

Figure 2. Impact factor of the journal Agronomy for Sustainable Development (ASD). Note the increase in the impact factor from 0.566 in 2003 to 1.000 in 2007 (+77\%). In 2006 the journal had two impact factors due to title change in 2005: 0.863 for the old title, Agronomie, and 0.306 for the new title, ASD. Those factors are not shown in the graph above because their calculation is different from that of normal impact factors. Specifically, the value for the old title is higher because it takes into account only older articles (2004) that thus have higher chances of getting cited (see scientific.thomsonreuters.com/isi for details).

of Agronomical Research (INRA, international.inra.fr). The journal is managed by a collaboration of two INRA departments, the Department of Environment and Agronomy (http:// www.inra.fr/ea), and the Department of Sciences for Action and Development (http://www.inra.fr/sad). Journal issues are produced by EDP Sciences (edpsciences.org). Our Editorial board collaborates with 3 Associate Editors and 32 Field Editors for manuscript peer-review. ASD publishes research and review articles. Submitted articles are first evaluated by a PreSelection Committee that declines about $50 \%$ of incoming manuscripts. Selected submissions are then sent to Field Editors for in-depth evaluation. The global rejection rate was $77 \%$ in 2006. The current impact factor (2007) is 1.000, ranking the journal 25/49 in the category Agronomy (Fig. 2).

ASD Journal was greatly reformed from 2003 to 2006 . We changed topics from classical, production-oriented agronomy to sustainable and ecological agriculture (Lichtfouse et al., 2004; Alberola et al., 2008). We integrated social and economic sciences by setting up a collaboration between the INRA Department of Environment and Agronomy and the INRA Department of Sciences for Action and Development. Major journal topics currently include:

- Agriculture and global changes;

- Agricultural production of renewable energies;

- Ecological pest control and biopesticides;

- Organic farming;

- Genetically modified organisms in cropping systems;

- Environmental impact on soil, water, air and biodiversity;

- Risk assessment for food, ecotoxicology;

- Decision support systems and companion modelling;

- Social and economic issues of agricultural changes;

- Innovation in farming systems;

- Pollutants in agrosystems.
Major journal changes implemented during the journal renovation are shown in Table I. They include: the setting up of a pre-selection committee at the submission stage; an increase in the number of Field Editors from 14 to 32; novel topics focusing on sustainable agriculture (Lichtfouse et al., 2004); novel format instructions for more concise articles; a novel title (formerly Agronomie); a switch from hardcopy to fully electronic managing; $100 \%$ of articles in English and a novel journal cover; and 7 review reports produced per manuscript: 3 reports from Associate Editors at the pre-selection step, 1 report from the Field Editor, 2 reports from peer-reviewers and 1 report from the Editor-in-Chief; active commissioning of review articles by the Editor-in-Chief. As a consequence, we have observed several positive trends during the last few years (Tab. I). The impact factor increased from 0.566 in 2003 to 1.000 in 2007 (+ 77\%, Fig. 2). The rejection rate increased from $44 \%$ in 2003 to $77 \%$ in 2006 . The number of submissions increased from 108 in 2003 to 211 in 2007 (+ 95\%). The number of pdf article downloads at the ASD website increased from 89158 in 2004 to 231504 in 2007 (+ 160\%). The number of subscribers to the free e-mail alert increased from 417 in 2004 to 1307 in $2007(+213 \%)$. The number of published review articles increased from 3 in 2005 to 13 in $2008(+333 \%)$.

From 2005, review articles are published both in ASD and in the book series Sustainable Agriculture (Lichtfouse et al., 2009). The first volume is scheduled to be issued in early 2009. A call for review articles for the next volumes is posted on the ASD website (agronomy-journal.org). To conclude, the trends observed are very promising to encourage scientists to publish their best results in ASD. In the next section we discuss views on sustainable agriculture.

\section{SUSTAINABLE DEVELOPMENT AND SUSTAINABLE AGRICULTURE}

The term "sustainable development" was first defined in 1987 by the Brundtland Commission, formally the World Commission on Environment and Development, solicited by the United Nations:

\section{Sustainable development is development that meets the needs of the present without compromising the ability of future generations to meet their own needs.}

This concept was then enhanced by the United Nations Conference on Environment and Development at the Earth Summit, Rio de Janeiro, in 1992. From that time, sustainable development became a key issue in political and scientific bodies, e.g. the Intergovernmental Panel on Climate Change (IPCC, ipcc.ch), the Millennium Ecosystem Assessment (millenniumassessment.org) and more recently, the Grenelle de l'Environnement in France (legrenelle-environnement.fr). The concept of sustainable development is well accepted by a large public because it has defined global stakes, but is very vague about the practical ways of reaching those stakes.

Sustainable agriculture does not escape this weakness, as shown by many reports (Hansen, 1996; Hansen and Jones, 
Table I. Major changes in the journal Agronomy for Sustainable Development (ASD) from 2003 to 2006.

\begin{tabular}{lcc}
\hline & BEFORE RENOVATION & ACTUAL \\
\hline Title & Agronomie & Agronomy for Sustainable Development \\
Field Editors & 14 & 32 \\
Pre-selection Committee & None & 3 Associate Editors \\
Topics & Conventional agronomy & Sustainable agronomy \\
Research article format & No size limit & Short articles \\
Language & $93 \%$ English & $100 \%$ English \\
Submissions per year & 108 & 211 \\
Pre-selection rejection $(\%)$ & 0 & 50 \\
Global rejection $(\%)$ & 44 & 77 \\
Research articles per year & 79 & 44 \\
Review articles per year & 3 & 18 \\
Impact factor & 0.566 & 1.000 \\
Acceptance delay & 10.3 months & 3.8 months \\
Article management & Hardcopy, post & $100 \%$ electronic, pdfs \\
Article pdf downloads $(/ y r)$ & 89158 & 231504 \\
E-mail alert subscribers & 417 & 1307 \\
\hline
\end{tabular}

1996; Gliessman, 1998; Gold, 1999; Tilman et al., 2002; Boiffin et al., 2004; Dupraz, 2005). Many authors and organisations worldwide give their own definition of sustainable agriculture. Some authors consider sustainable agriculture as a set of management strategies addressing the main societal concerns about food quality or environment protection (Francis et al., 1987). Other authors focus on the ability of agricultural systems to maintain crop productivity over the long term (Ikerd, 1993). Other authors focus on one main factor of sustainability; for instance, flexibility, which is the adaptive capacity of agriculture to adapt to future changes (Gafsi et al., 2006). Overall, all authors agree on the occurrence of three approaches to the concept of sustainable agriculture: environmental, economic and social approaches. In other words, agricultural systems are considered to be sustainable if they sustain themselves over a long period of time, that is, if they are economically viable, environmentally safe and socially fair. Beyond this ideological definition, the practical issue is to build operational solutions to reach global goals. This is a challenging task because the stakeholders do not agree on the criteria to measure the sustainability of a farming system, and on how to balance those criteria. Many indicators have indeed already been produced to evaluate sustainability.

The link between sustainable agriculture and sustainable development is not obvious (Legrand et al., 2002). Sustainable agriculture could involve two approaches (Boiffin et al., 2004). The first approach is that agriculture should sustain itself over a long period of time by protecting its productive resources, e.g. maintaining soil fertility, protecting groundwater, developing renewable energies, and finding solutions to adapt farming systems to climate change. This first approach considers the farming system as a closed area. The second approach is to consider that agriculture also has to contribute to the sustainability of large territories and social communities. Accordingly, agriculture should help urban areas to manage wastes, e.g., by recycling urban sewage sludge, developing rural employment, and offering a rural landscape for urban peo- ple. This second approach has wider goals and does not separate rural and urban areas. To conclude, the vagueness of the concept of sustainable development and sustainable agriculture is a strength because it does not restrict the research field too much, and, in turn gives freedom to scientists to explore wide, unknown domains.

\section{FUTURE SUSTAINABLE FARMING SYSTEMS}

After the Second World War, the development of conventional farming, or "industrial farming", was promoted in order to increase sharply food production worldwide. This social aim led to extensive use of pesticides, fertilisers and water, and to fast crop rotations and monoculture. Positive effects on yield were rapidly counterbalanced by negative environmental impacts such as soil erosion, groundwater pollution, river eutrophication, excessive water use, and the development of weeds and diseases resistant to chemical control. Industrial farming and other industrial activities have indeed led to the presence of pesticides and persistent organic pollutants in soils, water, air and food (Lichtfouse and Eglinton, 1995; Lichtfouse, 1997a; Lichtfouse et al., 1997, 2005a).

Today, to reach economic profitability, environmental safety and social fairness, farming systems should use fewer inputs and resources without drastically reducing yields. As the population is forecasted to increase to 9 billion in the next 50 years, it is necessary to maintain a high level of food production. Nonetheless, farming systems should also meet food quality policies enforced by national and international policies. This issue is particularly relevant given the occurrence of pesticide residues in food products because consumers and environmental associations are concerned about a possible new sanitary crisis. Pesticide use by farmers is thus widely criticised. On the other hand, decreasing pesticide use may lead to negative effects such as toxin risk in food (Le Bail et al., 2005). To reach more sustainable practices, several strategies 
are described in the literature. Those strategies involve various changes, from simple adjustment of the crop management sequence to fundamental changes at the farming system level. For example, MacRae et al. (1989) proposed the following framework based on three strategies: efficiency - substitution - redesign (ESR).

\subsection{Level 1: the substitution strategy}

This level refers to the substitution logic, meaning that existing farming systems are only slightly adapted, but not fundamentally altered (Altieri and Rosset, 1996). For instance, toxic chemicals and mineral fertilisers (NPK) should be replaced by compounds that are less pollutant, less persistent in soil and less energy-consuming. Applying biopesticides and growing genetically modified plants should decrease both pest development and the use of toxic pesticides. Growing symbiotic $\mathrm{N}$ legumes instead of applying costly, energy-consuming $\mathrm{N}$ fertilisers should also improve sustainability. Here, research is usually done at the plot level, which is the most common level for agronomists. Collaborations with scientists studying elementary processes, such as geochemists, pathologists and biologists, should be fostered. The substitution logic should be effective for a short time period because it allows a substantial reduction of chemical treatments. However, it may be not be efficient in the long run due to the appearance of pest resistance following the use of biopesticides, for instance.

\subsection{Level 2: the agroecological strategy}

The principle of the agroecological strategy is to build innovative technical scenarios relying on biological regulations in an integrated crop production scheme. This strategy involves applying ecological concepts and principles to the design, development and management of sustainable agricultural systems. Promoting biodiversity in agrosystems provides ecological services such as nutrient cycling, soil structuration and disease control. Biodiversity can be enhanced by cultural practices such as intercropping, rotation, agroforestry, composting and green manuring. Recent studies also address new issues in integrated pest management by combining the use of biological, physical, cultural and genetic control measures (Gurr et al., 2004). Increasing biodiversity by crop rotations (combination in time), intercropping (combination in space) and varietal mixtures has been suggested as an alternative to chemicals (Vandermeer et al., 1998). At this level, agronomy should interact with landscape ecology, because spatial variations in the landscape may be used for pest management. The productivity of farming systems should be increased by developing ecological principles and adapting them to farming systems. The agroecological strategy thus requires the enlargement of the experimental scale. Experimental scenarios should not be designed at plot level, but at the scale of larger territories. Therefore, investigations need a much better understanding of interactions of living organisms at plot and larger levels. They also require input from other disciplines such as ecology and geography.

\subsection{Level 3: the global strategy}

The principle of the global strategy is to solve agricultural issues at the global scale, by rethinking its relation to society. Indeed, most failures of intensive agriculture are closely linked to its economic model. There are fundamental contradictions among several aims assigned to agriculture. For instance, producing more and cheaper food products without polluting soils; and producing fruits and vegetables without pesticide residues and without visual pest damage appear to be unrealistic aims. Therefore, the global strategy relies on rethinking the role of agriculture in our society, as shown by new trends in agroecology (Gliessman, 2006). This approach considers that sustainability cannot be solely reached by farming systems, but should also involve the food system, i.e. the relations between farms and food consumption, and the marketing networks. For example, authors studying the relationships between production and marketing highlighted the interest in alternative food networks focused on local production (Lamine and Bellon, 2008). The global strategy thus requires interdisciplinary work with scientists from various sciences such as agronomy, ecology, sociology, economics and politics.

\section{AGRONOMICAL RESEARCH FOR SUSTAINABLE AGRICULTURE}

Agronomy was first defined as the science of crop production. It was mainly focused on the study of relationships between climate, soil, cultural practices, and crop yield and quality. Agronomy therefore integrates sciences such as biology, chemistry, soil science, ecology and genetics. Agronomists then enlarged their studies to the individuals performing the cultural practices, namely farmers. This approach raised new issues on the modelling of farmers' practices, and on the consequences of farmers' choices on crop production. Agronomists further analysed environmental impacts of farmers' practices. More recently, they have also studied how agriculture could benefit from the environment and ecosystems to improve crop production, thus leading to the concept of "ecological services".

To study crop production, agronomists have to integrate highly complex sciences that rule farming systems at very different spatial and temporal scales. Agronomists also have to cope with a high environmental variability. As a consequence, results obtained in an experimental field may not be reproducible in another field due to slight - possibly unknown variations in soil and climate factors. Therefore, a key point of agronomical investigations is to define the validity domain of each finding. Concerning the integration of agricultural practices, a key point is to enlarge the classical scales of crop production studies, "plant and plot", to scales that are meaningful for the farmers, such as combination of plots and farm territory, and even larger scales. In a way, agronomy is a science of complexity aimed at integrating knowledge at various spatial levels from the molecule to the living organism, the farming system and the global scale. Thus, agronomy appears more and more to be the science relevant for global issues because 
it integrates knowledge from various sciences at various spatial scales. Considered for a long time as a soft, side science, agronomy is rising fast as a central science because current issues are about food, and humans eat food.

The systemic dimension is essential because in the next few decades most improvements of farming systems will rely on enhancing positive interactions among various parts of farming systems. To build sustainable farming systems, agronomists will not only have to assess the direct effects of techniques on a crop, but also the indirect effects on the whole ecosystem such as biodiversity changes, water pollution and soil erosion. The economic and social consequences of the new farming systems should also be evaluated with a pluridisciplinary approach with economists or social scientists. Therefore, sustainable agriculture fosters the development of multidisciplinary studies that associate agronomy with ecology, economics, sociology and geography (Lichtfouse et al., 2004). Meynard et al. (2006) identified four different ways to design innovative agricultural systems for sustainable development:

- inventing new farming systems, breaking off with the current ones;

- identifying and improving farming systems built by the local stakeholders;

- giving tools and methods to stakeholders to improve their own systems or evaluate those proposed by scientists;

- identifying the economic, social and organisation conditions that may help the actors to adopt alternative farming systems.

These approaches raise several new issues for agronomical scientists. For instance, it is not clear whether solutions will be found either by only a slight adaptation of research practices or by a sharp change in experimentation and modelling. Studying new spatial scales that show heterogeneous areas such as field margins will be a challenge. The integration of long-term changes in farming systems, such as soil organic matter turnover (Lichtfouse, 1997b) and sewage sludge pollution (Lichtfouse et al., 2005b), should also be investigated and modelled because concepts of resilience and flexibility are relevant. It should also be noted that some farmers already have an accurate expertise in sustainable practices. Some are even ahead of research and are experimenting with new systems for, e.g., organic farming. Here, the issue for the agronomist is to build effective methods to gather local knowledge, to check findings and eventually to redesign experiments. Innovative agricultural systems will benefit from a close collaboration between scientists and farmers.

\section{REFERENCES}

Alberola C., Lichtfouse E., Navarrete M., Debaeke P., Souchère V. (2008) Agronomy for Sustainable Development, Ital. J. Agron. 3, 77-78.

Altieri M., Rosset P. (1996) Agroecology and the conversion of largescale conventional systems to sustainable management, Int. J. Environ. Stud. 50, 165-185.

Boiffin J., Hubert N., Durand N. (2004) (Eds.) Agriculture et développement durable, Enjeux et questions de recherche, INRA, mission communication, 92 p. ISSN1156-1653.

www.inra.fr/les_partenariats/programmes_anr/agriculture_et_ devedeveloppement_durable/documentation.

Dupraz (2005) Entre agronomie et écologie : vers la gestion d'écosystèmes cultivés, Revue DEMETER, 16 p., http://www.montpellier.inra.fr/safe/publications/papers/Dupraz\% 20article\%20pour\%201a\%20revue\%20Demeter.pdf.

Francis C.A., Sander D., Martin A. (1987) Search for a sustainable agriculture: reduced inputs and increased profits, Crops Soils Mag. 39, $12-14$.

Gafsi M., Legagneux B., Nguyen G., Robin P. (2006) Toward sustainable farming systems: effectiveness and deficiency of the French procedure of sustainable agriculture, Agr. Sys. 90, 226-242.

Gliessman S. (1998) Agroecology: ecological processes in agriculture, CRC Press, Michigan, $357 \mathrm{p}$.

Gliessman S. (2006) Agroecology: the ecology of sustainable food systems, CRC Press, 2 nd ed., 384 p.

Gold M. (1999) Sustainable agriculture: definitions and terms, Special reference briefs 99-02, USDA National Agricultural Library (NAL), ISSN 1052-5368, http://www.nal.usda.gov/afsi/AFSI_pubs/srb9902.htm.

Gurr G.M., Wratten S.D., Altieri M.A. (2004) Ecological engineering for pest management, CSIRO Publishing, 244 p.

Hansen (1996) Is agricultural sustainability a useful concept? Agr. Syst. $50,117-143$.

Hansen J.W., Jones J.W. (1996) A systems framework for characterizing farm sustainability, Agr. Syst. 51, 185-201.

Ikerd (1993) The need for a system approach to sustainable agriculture, Agr. Ecosyst. Environ. 46, 147-160.

Lal R. (2008) Soils and sustainable agriculture. A review, Agron. Sustain. Dev. 28, 57-64.

Le Bail M., Verger P., Dore T., Fourbet J.F., Champeil A., Ioos R., Leblanc J.C. (2005) Simulation of consumer exposure to deoxynivalenol according to wheat crop management and grain segregation: Case studies and methodological considerations, Regul. Toxicol. Pharm. 42, 253-259.

Legrand P., Fraval A., Laurent C. (2002) INRA faced with Sustainable Development: Landmarks for the Johannesburg Conference (english version), Dossiers de l'Environnement de l'INRA n ${ }^{\circ} 22$, Paris, 212 p., INRA Éditions, ISBN: 2-7380-1049-0, http://www.inra.fr/ dpenv/do22-e.htm.

Lamine C., Bellon S. (2008) Conversion to organic farming: a multidimensional research object at the crossroads of agricultural and social sciences. A review, Agron. Sustain. Dev., DOI: 10.1051/agro:2008007.

Lichtfouse E. (1997a) (Ed.) Soil Pollutants, Analusis Magazine 25, M16-M72.

Lichtfouse E. (1997b) Heterogeneous turnover of molecular organic substances from crop soils as revealed by ${ }^{13} \mathrm{C}$ labeling at natural abundance with Zea mays, Naturwissenschaften 84, 22-23.

Lichtfouse E., Budzinski H., Garrigues P., Eglinton T. I. (1997) Ancient polycyclic aromatic hydrocarbons in modern soils: ${ }^{13} \mathrm{C},{ }^{14} \mathrm{C}$ and biomarker evidence, Org. Geochem. 26, 353-359.

Lichtfouse E., Eglinton T.I. (1995) ${ }^{13} \mathrm{C}$ and ${ }^{14} \mathrm{C}$ evidence of pollution of a soil by fossil fuel and reconstruction of the composition of the polluant, Org. Geochem. 23, 969-973. 
Lichtfouse E., Habib R., Meynard J.M., Papy F. (2004) Agronomy for sustainable development, Agronomie 24, 445.

Lichtfouse E., Sappin-Didier V., Denaix L., Caria G., Metzger L., Amellal-Nassr N., Schmidt J. (2005b) A 25-year record of polycyclic aromatic hydrocarbons in soils amended with sewage sludges, Environ. Chem. Lett. 3, 140-144.

Lichtfouse E., Schwarzbauer J., Robert D. (2005a) (Eds.) Environmental Chemistry, Green Chemistry and Pollutants in Ecosystems. 1. Analytical Chemistry. 2. Toxic Metals. 3. Organic Pollutants. 4. Polycyclic Aromatic Compounds. 5. Pesticides. 6. Green Chemistry. 7. Ecotoxicology, Springer, 780 p., ISBN 3540228608, http://www.springerlink.com/content/n8078j/.

Lichtfouse E., Navarrete M., Debaeke P. (2009) (Eds.) Sustainable Agriculture, Vol. 1, Springer, EDP Sciences, in press.
MacRae R.J., Hill S.B., Henning J., Mehuys G.R. (1989) Agricultural science and sustainable agriculture: a review of the existing scientific barriers to sustainable food production and potential solutions, Biol. Agric. Hortic. 6, 173-219.

Meynard J.M., Aggerri F., Coulon J.B., Habib R., Tillon J.P. (2006) Recherches sur la conception de systèmes agricoles innovants, Rapport du groupe de travail, septembre 2006, 72 p.

Tilman D., Cassman K.G., Matson P.A., Naylor R., Polasky S. (2002) Agricultural sustainability and intensive production practices, Nature 418, 671-677.

Vandermeer J., van Noordwijk M., Anderson J., Ong C., Perfecto I. (1998) Global change and multispecies agroecosystems: Concepts and issues, Agr., Ecosyst. Environ. 67, 1-22. 